\title{
Groundwater Quality Assessment in Eti-Osa, Lagos-Nigeria using Multivariate Analysis
}

\section{*AKOTEYON, I S; SOLADOYE, O}

\author{
Department of Geography and Planning, Lagos State University, Ojo, Lagos-Nigeria
}

\begin{abstract}
Groundwater quality in Eti-Osa was assessed. 18 water samples were collected from hand dug well and measured for 3 physical (pH, EC and TDS) and 9 chemical parameters $(\mathrm{Ca}, \mathrm{Cl}, \mathrm{Fe}, \mathrm{TH}, \mathrm{Mg}, \mathrm{NO}$, $\mathrm{SO}_{4}, \mathrm{TSS}$ and $\mathrm{Zn}$ ) after standard procedures (APHA). The results show that $\mathrm{pH}$ of groundwater samples indicates a neutral condition (7.01). TH was slightly hard (37.11mg/l). TDS, Fe and $\mathrm{Mg}$ concentrations were above the NDWQS limit of $(500,0.3$ and $0.2 \mathrm{mg} / \mathrm{l})$ respectively for drinking water purpose. The Coefficient of variation shows that all the groundwater parameters with the exception of $\mathrm{pH}, \mathrm{Ca}, \mathrm{Cl}$ and $\mathrm{Fe}$ are highly heterogeneous. The correlation among the groundwater parameters shows that $\mathrm{pH}$ has a negative correlation at $P<\mathbf{0 . 0 5}$ with Ca and TSS $(r=-0.49)$. TH and Ca showed a positive correlations with $\mathrm{Cl}(\mathrm{r}=0.51), \mathrm{EC}(\mathrm{r}=0.58)$. The factor analysis employed indicates four factors. Factor I, explains $27.73 \%$ of the total variance, with a strong positive loading on $\mathrm{EC}$, TDS, Ca and a negative loading on $\mathrm{pH}$. Factor II accounts for $21.35 \%$ of the total variance, and was characterized by strong positive loading of $\mathrm{Zn}$ and negative loading of Fe and TDS.Factor III was characterized by high positive loading of $\mathrm{Cl}$ and $\mathrm{TH}$ and accounts for $15.98 \%$ of the total variance while factor IV accounts for $14.05 \%$ of the total variance and was characterized by a strong positive loading of $\mathrm{NO}_{3}$. The paper recommended routine monitoring and thorough treatment before consumption. The study demonstrates the effectiveness of factor analysis in assessing the hydrochemical processes of groundwater in the area. @JASEM
\end{abstract}

Groundwater constitutes an important source of water for drinking, agriculture and industrial production. The use of groundwater has increased significantly in the last decades due to its widespread occurrence and overall good quality. The contribution from groundwater is vital; because about two billion people depend directly upon aquifers for drinking water, and 40 percent of the world's food is produced by irrigated agriculture that relies largely on groundwater (Morris et al., 2003).Despite its importance, contamination from natural, human activities, steady increase in demand for water due to rising population and per capita use, increasing need for irrigation, changes in climates and overexploitation etc)among others has affected the use of groundwater as source of drinking water. In Nigeria, regulatory agencies (Standard Organization of Nigeria (SON), Federal Ministry of Environment (FME) among others are established for the enforcement of national water quality and emission standards in order to protect human health and aquatic ecosystems. In term of effectiveness of these agencies, the decree that established them can be described as stale judging from the punitive contents which can best be described as a disincentive and invitation to chaos. The penalties for defaulters are cheaper and paying such a pittance as fine saves them more money than the actual objective for which the decree was made.

Access to sources of water in Nigeria shows that $48 \%$ (about 67 million Nigerians) depend on surface water for domestic use, $57 \%$ (79 million) use hand dug wells, 20\% (27.8 million) harvest rain, 14\% (19.5 million) have access to pipe borne water, and $14 \%$ have access to borehole water sources (FGN,2007).Globally, about $80 \%$ of all diseases and death in developing country are water-related as a result of polluted water (Ayeni et al; 2011, Aderibigbe et al; 2008).

Among the multivariate techniques, R-mode factor analysis has been widely employed for understanding hydrogeochemical association and processes controlling them ( Briz-kishore and Murali, 1992; Ravi, 1999 and Rao, et al., 2001). As a first step, correlation analysis that reveals the relationship between two variables was calculated for the major ion in groundwater samples in the study area. Though factor analysis reduces the dimensionality of the problem, the meaning of these factors may sometimes be difficult to deduce (Davis, 1986).

In this study, Kaiser varimax rotation was applied for the multivariate analysis of groundwater quality parameters. The final step of the factor analysis projected the data on the rotated significant factors and the scores obtained by this projection (factor scores) are used to understand the nature of variables. According to Dalton and Upchurch (1978) factor scores are related to the intensity of the chemical processes described by each factor. Negative numbers reflect areas unaffected by the process, positive numbers indicate areas most affected and near-zero numbers affect to an average degree (Lawrence and Upchurch, 1982).

This study examined the governing factors of groundwater quality based on multivariate analysis technique in the study area.

The Study Area: Eti-Osa Local Government Area is located between latitude $6^{\circ} 15^{\prime}$ and $16^{\circ} 17^{\prime}$ and longitude $3^{0} 3^{\prime}$ east and $3^{0} 35^{\prime}$ east. It is bounded in the south by Atlantic Ocean, in the east by Ojo local government, north by Lagos lagoon and part of Mainland and Island local government and in the 
west by Ibeju- Lekki local government (Odumosu et al., 1999). The study area occupies an area of about $192.3 \mathrm{~km}^{2}$.The population is about 287,785 with density of 1,496 person per $\mathrm{km}^{2}$ (NPC, 2006). The study area houses the Lagos lagoon and the beaches, which stretch to the Atlantic Ocean. It comprises of nine wards namely; Victoria Island, Ward $\mathrm{H}_{1}$ and $\mathrm{H}_{2}$, Ikoyi West, Ward $\mathrm{L}_{1}$, Ikoyi East, Ward $\mathrm{L}_{2}$, Obalende, Ward $_{\mathrm{M}}$, Eti-Osa N. E, Ward $\mathrm{K}_{3}$, Eti-Osa, S. E, Ward $\mathrm{K}_{2}$, Eti - Osa N.W, Ward $\mathrm{K}_{1}$, and Eti - Osa S.W, Ward.

The climate is tropical type with an average rainfall of $2500 \mathrm{~mm}$ and temperature of $30^{\circ} \mathrm{C}$. The vegetation pattern reflects its coastal location with mangrove swamp trees being the dominant type. The topography is between $3-15 \mathrm{~m}$ above sea level. The geology consists of quaternary alluvial deposits such as red-yellow, red-brown, grey and sandy- clays, silt, sand, gravels, and other detrital material. The major source of water provision in the study area includes pipe-borne water and boreholes.

\section{MATERIAL AND METHODS}

Reconnaissance survey of the study area was carried out prior to the actual sample collection. The reconnaissance survey facilitated a better understanding of the spatial distribution of wells within the study area. Groundwater samples were collected during the month of June, 2009 at eighteen (18) sampling points using a random sampling technique. Three (3) physical parameters were measured for $\mathrm{pH}$, Electrical Conductivity and Total Dissolved Solids while nine (9) chemical parameters were analyzed for Total Suspended Solids, Total Hardness, Calcium, Magnesium, Chloride, Nitrate, Sulphate, Zinc and Iron using standard methods for water samples examination after American Public Health Association 1998.

The co-ordinates of the sampling points were recorded using Global Positioning System (GPS) Garmin Channel 72 model. Well water samples were collected in clean 1.5 litre plastic jar with screw caps, and packed in cooler containing ice and transported to the laboratory within 24hours from the time of sample collection.

The in situ measurement was carried out using potable digital meter, EXTECH $\mathrm{pH}-100$ and HM digital EC/TDS/Temperature COM-100 respectively. Total Hardness and Chloride were determined using titrimetry method. The concentrations of metals (Iron, Zinc, Magnesium and Calcium) were determined by Atomic Absorption Spectrophotometer (AAS) while Total Suspended Solids, Sulphate and Nitrate were determined using $\mathrm{HACH}$ DR/2000 direct reading spectrophotometer.

\section{RESULTS AND DISCUSSION}

Table 1 presents the statistics of groundwater parameters in the study area. It was observed that the
$\mathrm{pH}$ in all the groundwater samples ranges from 6.79 to 7.22 with a mean of $7.01 \mathrm{mg} / \mathrm{l}$, indicating a neutral condition. The $\mathrm{pH}$ values are within the prescribed limits of 6.5-8.5 for drinking water standards.

The results show that Total Hardness varied between 27.21- 47.02, with a mean of $37.11 \mathrm{mg} / 1$, indicating the groundwater Quality of the study area is slightly hard. The TDS, which is an indicative parameter to assess the degree of water quality, varied between 437.43 - 777.46 with a mean of $607.44 \mathrm{mg} / \mathrm{l}$. The TDS values were above the prescribed limits of $500 \mathrm{mg} / \mathrm{l}$ for drinking water purpose. TDS in groundwater are generally not harmful to human being but high concentration may affect persons, who are suffering from kidney and heart diseases (Gupta, 2004).

Water containing high solids may also cause laxative or constipation effects. The concentration $(\mathrm{mg} / \mathrm{L})$ of Calcium, Magnesium, Chloride, Sulfate and Nitrate are in the range of $12.72-19.50,1.44-3.97,178.55-$ $265.89,1.31-2.29$ and $0.52-1.02$ with a mean of $16.11,2.71,222.22,1.80$ and 0.77 respectively.

Compared to Nigerian Drinking Water Quality Standards (NDWQS), the concentration of $\mathrm{Ca}, \mathrm{Cl}$, $\mathrm{SO}_{4}$ and $\mathrm{NO}_{3}$ are below the safe limit of 300, 250, 100 and $50 \mathrm{mg} / \mathrm{L}$ for drinking, respectively whereas, concentration of $\mathrm{Mg}(2.71 \mathrm{mg} / \mathrm{l})$ was above the permissible limits of $0.2 \mathrm{mg} / \mathrm{l}$ for drinking purpose.

Since the chloride-rich minerals are not found in the study area, the higher concentrations of chloride in the groundwater could be caused by pollution sources such of domestic wastewater and septic tanks. Iron content varies from $0.56-0.79 \mathrm{mg} / \mathrm{l}$, with a mean of $0.66 \mathrm{mg} / \mathrm{l}$. The concentration of $\mathrm{Fe}(0.66 \mathrm{mg} / \mathrm{l})$ is above the prescribed limits of $0.3 \mathrm{mg} / \mathrm{l}$ for drinking water standards. On the pattern of relative variation, the result of the Coefficient of variation (C.V) shows that all the examined groundwater variables with the exception of $\mathrm{pH}, \mathrm{Ca}, \mathrm{Cl}$ and $\mathrm{Fe}$ are heterogeneous. Considering the high variability of groundwater parameters in the study area, there is need for routine monitoring and thorough boiling before consumption of groundwater quality.

Table 2 presents the correlation among various parameters of groundwater in the study area. $\mathrm{pH}$ shows a negative correlation at $\mathrm{p}<0.05$, with $\mathrm{Ca}$ and TSS (r=-0.49). Similarly, Fe shows a negative correlation with $\mathrm{Zn}(\mathrm{r}=-0.49)$ while $\mathrm{TH}$ and $\mathrm{Ca}$ showed a positive correlations with $\mathrm{Cl}(\mathrm{r}=0.51)$, EC $(\mathrm{r}=0.58)$ respectively. Since correlation analysis reveals similarities or differences in the behavior of pairs of ions, and does not conveniently identify groups of ions that behave similarly, factor analysis was carried out for the groundwater parameters to help in hydrogeochemical interpretation of the data. Result of factor analysis of the groundwater chemistry indicates four factors (Table 3) that can be 
related to various controlling processes of hydrochemistry. The rotated factor matrix statistics show that the four factors extracted explain $77.11 \%$ of total variance. The communalities of the variables and proportion of their variance explained by the extracted common factors vary from 0.72 to 0.89 , suggesting the factor analysis model can be represented adequately based on the overall variance of the data set. Factor I, which explains $27.73 \%$ of the total variance, has a strong positive loading on $\mathrm{EC}$, TDS, $\mathrm{Ca}$ and a negative loading on $\mathrm{pH}$. It further shows moderate loadings on $\mathrm{Mg}$ and $\mathrm{Zn}$ while the loading on $\mathrm{Cl}, \mathrm{NO}_{3}$ and $\mathrm{Fe}$ depict a very low loadings. The negative loading of $\mathrm{pH}$ on factor I confirms that the concentration of $\mathrm{pH}$ in the groundwater does not contribute significantly to EC, TDS and Ca values.

Factor II accounts for $21.35 \%$ of the total variance, which is characterized by strong positive loading of $\mathrm{Zn}$ and negative loading of Fe and TDS. The rest of the variables show low to very low loadings. Factor III is characterized by high positive loading of $\mathrm{Cl}$ and TH which accounts for $15.98 \%$ of the total variance. Factor IV accounts for $14.05 \%$ of the total variance and is characterized by a strong positive loading of $\mathrm{NO}_{3}$. Nitrate is derived mainly from the nonlithological (Ritzi et al.,), which is caused by anthropogenic activities. For example, the association between $\mathrm{NO}_{3}$ - and $\mathrm{Na}^{+}$reflects the impact of domestic wastewater and septic tank.
The combination of TDS with $\mathrm{Cl}$ measures high salinity, $\mathrm{TH}(\mathrm{Ca}$ and $\mathrm{Mg}$ ) represents permanent hardness. According to Subba Rao et al (1997) enrichment of TDS and $\mathrm{Cl}$ is possible because of the effect of urban wastewaters. According to Hem (1991) water lost alkaline earth elements ( $\mathrm{Ca}$ and $\mathrm{Mg}$ ) through the exchange process and may later participate in chemical reactions, which raise the pH.The loadings on $\mathrm{Cl}$ and TDS are interpreted as representing the role of weathering of country rocks, climate and anthropogenic sources of groundwater contamination. Similarly, $\mathrm{Ca}$ and $\mathrm{Mg}$ reflect the weathering of country rocks (Mohan et al., 2000). Nitrate has no known lithologic source and hence it reveals pollution, which is attributed to the urban wastewaters and high density of septic tank (Uma, 1993; Ballukraya and Ravi, 1999).

Table 1: Descriptive Statistics of groundwater sample parameters All units except $\mathrm{pH}$ are $\mathrm{SD}=$ standard deviation;

LCL=lower confidence limit; UCL=upper confidence limit; $\mathrm{CV}=$ coefficient of variation

\begin{tabular}{|c|c|c|c|c|c|}
\hline Parameters & Mean & SD & LCL & UCL & CV (\%) \\
\hline $\mathrm{pH}$ & 7.01 & 0.43 & 6.79 & 7.22 & 6.13 \\
$\mathrm{TH}$ & 37.11 & 19.92 & 27.21 & 47.02 & 53.68 \\
$\mathrm{Ca}$ & 16.11 & 6.82 & 12.72 & 19.50 & 42.33 \\
$\mathrm{Mg}$ & 2.71 & 2.54 & 1.44 & 3.97 & 93.73 \\
$\mathrm{Cl}$ & 222.22 & 87.82 & 178.55 & 265.89 & 39.52 \\
$\mathrm{TDS}$ & 607.44 & 341.88 & 437.43 & 777.46 & 56.28 \\
$\mathrm{NO}_{3}$ & 0.77 & 0.50 & 0.52 & 1.02 & 64.94 \\
$\mathrm{Fe}$ & 0.66 & 0.19 & 0.56 & 0.76 & 28.79 \\
$\mathrm{SO}_{4}$ & 1.80 & 0.99 & 1.31 & 2.29 & 55.00 \\
$\mathrm{EC}$ & 1.32 & 0.69 & 0.98 & 1.67 & 52.27 \\
$\mathrm{TSS}$ & 6.78 & 5.98 & 3.82 & 9.74 & 88.20 \\
$\mathrm{Zn}$ & 4.44 & 4.89 & 2.03 & 6.89 & 110.14 \\
& & & & & \\
\hline
\end{tabular}

Table 2: Correlation Matrix of Groundwater parameter. Correlation is significant at the 0.05 level (2-tailed), in bold

\begin{tabular}{|l|l|l|l|l|l|l|l|l|l|l|l|l|}
\hline Parameters & $\mathrm{pH}$ & $\mathrm{TH}$ & $\mathrm{Ca}$ & $\mathrm{Mg}$ & $\mathrm{Cl}$ & $\mathrm{TDS}$ & $\mathrm{NO} 3$ & $\mathrm{Fe}$ & $\mathrm{SO} 4$ & $\mathrm{EC}$ & $\mathrm{TSS}$ & $\mathrm{Zn}$ \\
\hline $\mathrm{pH}$ & 1 & & & & & & & & & & & \\
$\mathrm{TH}$ & 0.06 & 1 & & & & & & & & & & \\
$\mathrm{Ca}$ & $\mathbf{- 0 . 4 9}$ & 0.19 & 1 & & & & & & & & & \\
$\mathrm{Mg}$ & -0.27 & 0.04 & 0.29 & 1 & & & & & & & & \\
$\mathrm{Cl}$ & 0.25 & $\mathbf{0 . 5 1}$ & 0.09 & 0.03 & 1 & & & & & & & \\
$\mathrm{TDS}$ & -0.39 & 0.18 & 0.65 & 0.36 & 0.23 & 1 & & & & & & \\
$\mathrm{NO} 3$ & -0.19 & -0.22 & -0.03 & 0.45 & 0.18 & 0.13 & 1 & & & & & \\
$\mathrm{Fe}$ & -0.10 & -0.21 & 0.05 & -0.39 & -0.08 & -0.16 & 0.12 & 1 & & & & \\
$\mathrm{SO} 4$ & 0.42 & 0.13 & -0.26 & -0.08 & 0.42 & -0.09 & 0.39 & 0.05 & 1 & & & \\
EC & -0.44 & 0.21 & $\mathbf{0 . 5 8}$ & 0.40 & 0.16 & 0.93 & 0.16 & -0.19 & -0.14 & 1 & & \\
TSS & $-\mathbf{0 . 4 9}$ & 0.02 & 0.34 & -0.34 & -0.13 & -0.06 & -0.22 & 0.67 & -0.43 & -0.05 & 1 & \\
Zn & -0.19 & 0.28 & 0.22 & 0.74 & 0.22 & 0.46 & 0.27 & $\mathbf{- 0 . 4 9}$ & 0.26 & 0.45 & $\mathbf{- 0 . 4 8}$ & 1 \\
\hline
\end{tabular}


Table 3: Rotated Factor Matrix Extraction Method: Principal Component Analysis. Rotation Method: Varimax with Kaiser Normalization.

\begin{tabular}{|c|c|c|c|c|c|}
\hline \multirow[t]{2}{*}{ Variables } & \multicolumn{4}{|c|}{ Components } & \multirow{2}{*}{ Communality } \\
\hline & Factor 1 & Factor II & Factor III & Factor IV & \\
\hline Hydrogen ion Concentration & -0.73 & 0.20 & 0.39 & -0.08 & 0.74 \\
\hline Total Hardness & 0.22 & 0.12 & 0.73 & -0.35 & 0.72 \\
\hline Calcium & 0.83 & -0.12 & 0.08 & -0.11 & 0.72 \\
\hline Magnesium & 0.47 & 0.62 & -0.16 & 0.35 & 0.75 \\
\hline Chloride & 0.09 & -0.01 & 0.86 & 0.18 & 0.79 \\
\hline Total Dissolve Solids & 0.84 & 0.21 & 0.20 & 0.05 & 0.79 \\
\hline Nitrate & 0.13 & 0.08 & -0.03 & 0.92 & 0.87 \\
\hline Iron & -0.02 & -0.88 & -0.01 & 0.29 & 0.86 \\
\hline Sulfate & -0.35 & 0.12 & 0.57 & 0.57 & 0.79 \\
\hline Electrical Conductivity & 0.84 & 0.23 & 0.14 & 0.05 & 0.79 \\
\hline Total Suspended Solids & 0.31 & -0.85 & -0.15 & -0.22 & 0.89 \\
\hline Zinc & 0.41 & 0.71 & 0.19 & 0.27 & 0.78 \\
\hline Eigen Values & 3.33 & 2.56 & 1.92 & 1.69 & \\
\hline \% of Variance & 27.73 & 21.35 & 15.98 & 14.05 & \\
\hline Cumulative \% of Variance & 27.73 & 49.08 & 65.06 & 79.11 & \\
\hline
\end{tabular}

Conclusion: The present study assessed the physicochemical characteristics of open hand dug well quality in Eti-Osa, Lagos-Nigeria .The NDWQS drinking water quality standards adopted show that TDS, Iron and Magnesium values were above the prescribed limits. Also, $\mathrm{TH}, \mathrm{Mg}$, TDS, $\mathrm{NO}_{3}, \mathrm{SO}_{4}, \mathrm{EC}$, TSS and $\mathrm{Zn}$ were highly variable. Result of the multivariate statistical analysis, as applied to the chemical data set of groundwater quality in the area provides an insight into the underlying controlling hydrochemical processes in study the area. Four factors including factor 1(EC, TDS, $\mathrm{Ca}$ and $\mathrm{pH}$ ), factor $2(\mathrm{Zn}, \mathrm{Fe}$ and $\mathrm{TDS})$, factor $3(\mathrm{Cl}$ and $\mathrm{TH})$ and factor $4\left(\mathrm{NO}_{3}\right)$ extracted from the dataset represent the signatures of weathering of country rock, climate and anthropogenic contamination, salinity and pollution respectively. This study demonstrates the effectiveness of factor analysis in assessing the hydrochemical processes of groundwater and also to provide preliminary assessment of the groundwater quality that will serve as a data base for future investigations and monitoring of groundwater quality in the study area. The paper recommends the need for routine monitoring and thorough boiling before consumption of groundwater quality. The recent drive towards urbanization and industrialization means a greater demand for groundwater and high rate of wastewater released onto the land surface. Hence, groundwater yield and appriopate laws guiding the release of wastewater onto the land should be strictly adhered to.

\section{REFERENCES}

Aderibigbe, S.A, Awoyemi, A.O and Osagbemi, G.K (2008): Availability, adequacy and quality of water supply in Ilorin metropolis, Nigeria.Eur.J. Scientific Res. Vol.23 pp.528-536.

American Public Health Association (APHA): (1998) American Water Works Association, Water Environment Federation (1998). Standard methods for examination of water and wastewater (20th ed.). New York, USA: American Public Health Association.

Ayeni,A.O,Balogun,I.I and Soneye,A.S.O (2011): Seasonal assessment of physico chemical concentration of polluted urban river:case of Ala River in Southwestern Nigeria.Research Journal of Environmental Science. Vol 5(1) pp.22-33.

Ballukraya, P.N. and. Ravi, R (1999): Characterization of groundwater in the unconfined aquifers of Chennai City, India.J. Geol. Soc. India, Vol. 54, pp. 13-22. 
Briz-kishore, B.H. and Murali, G. (1992): Factor analysis for revealing hydrogeochemical characteristics of a watershed.Environ. Geol., Vol. 19, pp. 3-9.

Dalton, M.G. and S.B. Upchurch; Interpretations of hydrogeochemical facies by factor analysis. Ground Water,Vol. 10, pp. 228-233; 1978.

Davis, J.C. (1986): Statistics and Data Analysis in Geology. John Wiley and Sons, $646 \mathrm{p}$

FGN. (2007). Legal Notice on Publication of the 2006 Census Report. Federal Government of Nigeria official Gazette, 4(94), 1-8.

Gupta, S. K. and Deshpande, R. D. (2004), "Water for India in 2050: first-order assessment of available options", Current Science, Vol. 86, No. 9, pp.1216-24.

Hem, J.D (1991): Study and Interpretation of the Chemical Characteristics of Natural Waters. 2254, 3rd ed. Scientific Publ., Jodhpur, India, $263 \mathrm{p}$

Lawrence, F.W. and Upchurch, S.B. (1982): Identification of recharge areas using geochemical factor analysis. Ground Water, Vol. 20, pp. 680-687.

Mohan, R., Singh, A.K., Tripathi, J.K. and Chowdhary, G.C. (2000): Hydrochemistry and quality assessment of groundwater in Naini Industrial Area, Allahabad district, Uttar Pradesh. J. Geol. Soc. India, Vol. 55, pp. 77-89.

Morris, B.L. et al. (2003), Groundwater and its susceptibility to degradation: a global assessment of the problem and options for management, Early Warning and Assessment Report Series,

United Nations Environment Programme, Nairobi, Kenya, Report RS 03-3: 126 p.

National Population Census (2006) Federal Republic of Nigeria Official Gazette Legal Notice on
Publication of the details of breakdown of the National and State Provisional Totals.

Odumosu T, Balogun Y.\& Ojo. K (1999). (ed) Lagos State in Maps, Rex Charles Publication, Ibadan pp 1-50

Offodile, M.E (2000): The Development and Management of Ground Water for Water Supply in Nigeria. Paper Presented at the 2nd Fellow's Workshop of NMGS 6th March ,2000

Priority Actions Programme / Regional Activity Centre, (1997): Integrated Approach to Development, Management and use of Water Resources.Eds. Margeta, J, Iacovide,I and Azzopardi, E Split, pp VI+154.

Subba Rao, N., Prakasa Rao, J., Chandra Rao, P., Niranjan Babu, P. and Krishna Rao, G. (1997) Hydrogeochemical zoning in crystalline terrain and its significance to water quality. J. Geol. Soc. India, Vol. 49, pp. 715-719

Subba Rao, N; Prakasa Rao, J; John Devadas, D; Srinivasa Rao, K. and Krishna ,C (2001): multivariate analysis for identifying the governing factors of groundwater quality. Journal of

Environmental Hydrology. Vol. 9 Paper 16 pp.1-9

Uma, K.O.(1993): Nitrates in shallow (regolith) aquifers around Sokoto town, Nigeria. Environ. Geol., Vol. 21, pp.70-76

United Nations Educational, Scientific and Cultural Organization Vrba,J \& Lipponen ,A (eds).(2007): Groundwater Resources Sustainability Indicators. I H P - VI s e r i e s On $\begin{array}{llll}\text { Groundwater } & \text { No. } & 1 & 4 .\end{array}$ Availableat:http://unesdoc.unesco.org/images/00 14/001497/149754E.pdf.Accessed October, $10^{\text {th }}$ 2010.

WHO (1993): Guidelines for Drinking-Water Quality.2 $2^{\text {nd }}$ Edn. Vol., 1.World Health Organization, Geneva. 